Jpn. J. Oral Biol., 26: 1368-1372, 1984.

\title{
A preliminary report on transplantation of adenoid cystic carcinoma
}

\author{
Shiroshi Kikuchi and Hiroko Kato-Kikuchi \\ Department of Oral Surgery, Teikyo University School of Medicine, \\ 2-11-1, Kaga, Itabashi-ku, Tokyo 173, Japan
}

[Accepted for publication: September 20, 1984]

\begin{abstract}
Key words: adenoid cystic carcinoma / oral cavity / nude mice / heterotransplantation / passage-transplantation
\end{abstract}

\section{Introduction}

Nude mice have been widely accepted as favorite experimental animals for malignant tumor-transplant study on various types of human cancers by many researchers ${ }^{1-3}$ ) since the report of Rygaard et al. ${ }^{4)}$. However, clinical cases of adenoid cystic carcinoma, especially of oral cavity are very less frequent $^{5)}$. Besides, few reports $^{6)}$ have appeared on the experimental transplantation of adenoid carcinomas because it is more difficult to transplant adenoid carcinomas to the nude mice than squamous cell carcinoma or many other types of cancer.

The goal of our study was to elucidate the proliferative and invasion patterns of the carcinoma, understand the biological behavior and nature, and establish a screening system for chemotherapy. Therefore, we attempted to transplant human adenoid cystic carcinoma from the floor of the mouth to the mice as the first step. Preliminary study for the transplantation was achieved with success. This study presents the transplantability of adenoid cystic carcinoma to the mice, the proliferative behavior, and the histological features of the transplant.

\section{Materials and Methods}

Three to four weeks-old nude mice, BALB/ C nu/nu strain (Nisseiken, Shizuoka Jikken Dobutsu) were placed in isolucs under laminal flow system in a conventional room, and fed on a sustenance food FR-2 (Funabashi Farm) and sterilized tap water. The animals were kept in this conventional room for a week or more after their arrival, and used after ensuring the sufficient recovery from the state of shock due to transfer.

Fresh cancer tissues were obtained aseptically from a patient with adenoid cystic carcinoma, washed in Hank's medium ${ }^{7)}$ $+10 \%$ FBS ( $\mathrm{pH} 7.2$ ), cut into small pieces, 2 to $3 \mathrm{~mm}$ size $^{8)}$, and transplanted subcutaneously to one side of the back with a transplantation needle.

Growth measurement of the transplanted tumors was carried out as follows; the mice with transplanted tumors were placed in a given position along a scale, and photographed periodically. The slides were put on the visual process system, MGG-1000 (Mutoh Kogyo K.K.) to measure the extent of the floor area of the tumors. After observation for a certain period, the mice were sacrificed after using anesthetics with ether and autopsied. At that time, the transplanted tumors in which the necrosis was removed if present, were used passage-transplantation, in the same manner as described above.

The judgment for transplantation depends on the active growth of the transplant in mice and the progressive increase in tumor volume. Some tissues from the clinical specimen and from the transplanted tumors of mice were prepared for light microscopy and the sections from the respective paraffin blocks were stained with hematoxylin and eosin. 


\section{Result's and Discussion}

Transplantability: A photograph of Fig. 1 shows a case which were judged to be positive following tumor transplantation. Successful transplantations were $3 / 3$ cases for primary heterotransplantation, $6 / 6$ for passage I, 8/10 for passage II, and $9 / 11$ for passage III. These results indicate that the strains of human adenoid cystic carcinoma in nude mice may be established successfully.

A few tumors, which were not grown in mice at passages II and III, disappeared in the course of transplantation, or after the growth was once observed. Such a disappearance of tumors has been reported by others ${ }^{9)}$. The less frequent transplantability at passages II and III appears to have resulted from various factors on both or either side of the tumors and hosts. There are some possible factors from the tumor side such as uneven distribution of vividly proliferative cells inside the tumor mass, and the difference in growth rate of transplanted tumor cells.

For possible factors from the host side, there are immune conditions of each mice such as the function of $\mathrm{T}$ cells $\mathrm{s}^{10,11)}$, antineoplastic capacity of macrophages ${ }^{12)}$ and the activity of natural killer cells ${ }^{13,14}$. In this study the wasting of the transplanted mice was found earlier than that of the control mice and the infections occurred in the former mice more frequently than on the average. These facts suggest cachexy and the presence of endogenous infectious

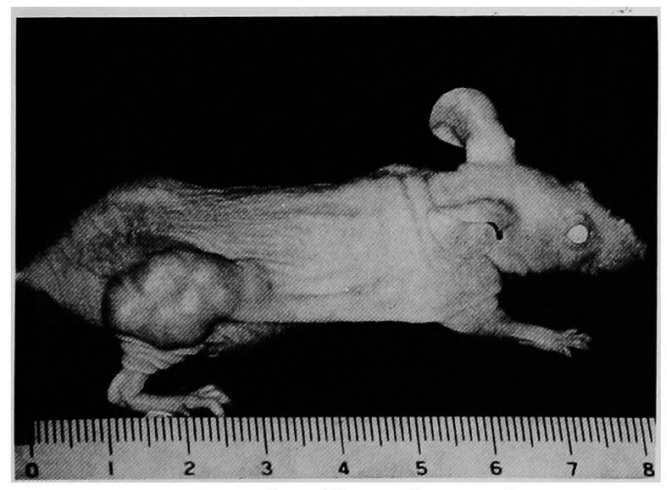

Fig. 1 An adenoid cystic carcinoma, transplanted to a nude mouse. factors. So we examined the infectious problems in nude mice obtained from various breeders. Recently we have obtained the transplantability of tumors at a level as high as $11 / 11$ cases at passage $\mathrm{V}$.

Growth of transplanted tumors: Figure 2 shows the growth curves. For primary heterotransplantation, about 5 weeks were required until a subcutaneous tumor grew from ca. 150 to ca. $300 \mathrm{~mm}^{2}$ in the floor area. The growth rate of tumors for passages I, II and III was faster than that for the primary heterotransplantation. Among their growth rates of tumors for passages I, II and III were similar curves. Since the growth results of tumors for the serial passages are stable, a model of experimental animals may be established in the near future.

To obtain the doubling time; In $\frac{2}{\text { slop }}{ }^{15}$ ) from growth curves at log phase, approximate tumor volumes were calculated from the floor areas of the subcutaneous one. The doubling times were 11.4 days for passage I, 11.0 days for passage II, and 10.6 days for passage III, which were given an average doubling time of 11.0 days for passages I to III.

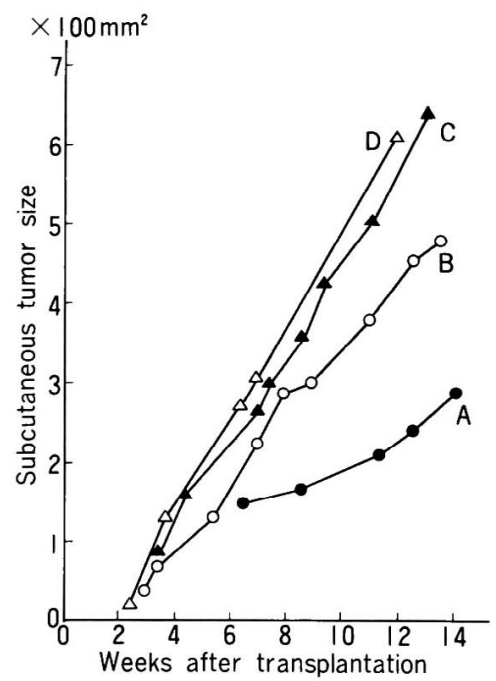

Fig. 2 Curves of growth rates in A (0) heterotransplantation, B (O) passagetransplantation I, C $(\Delta)$ passage II, $\mathrm{D}(\Delta)$ passage III. 
Ezaki et $a l{ }^{15)}$ described in the study of gastric cancer, which is poorly differentiated adenocarcinoma, the average doubling times were 8.1 days for passages I to XX, and 9.3 days for passages I to III, although they used a different method of transplantation from ours. Generally, adenoid carcinomas are slowgrowing types, and therefore they have longer clinical histories than others. But as for adenoid carcinomas, there are several differences between adenoid cystic carcinoma and adenocarcinoma. When our results were compared with theirs, adenoid cystic carcinoma grew slower than the gastric cancer. These results may reflect at least the differences in the growth tendency which are caused by some different types of cancers. It is known that, in most cases of tumors subcutaneously passage-transplanted in the mice, the growth rate is faster as the generation of passage elapses ${ }^{11)}$. The results obtained here showed similar growth rates.
Histology: The biopsied tumor from a patient showed the formation of insufficient small lumens in solid proliferative foci (Fig. 3a) as well as the heterotransplanted tumors in nude mice (Fig. 3b). The passagetransplantation I (Fig. 4a) and II (Fig. 4b) displayed the cribriform pattern and funiform arrangement which are seen in human adenoid cystic carcinoma. The plexiform, cribriform and medullar structures were apparently found in the passage III tumor (Fig. 5a) and the biopsied one (Fig. 5b). Histological examinations showed that there were many similarities in the cellular morphology and differentiation between the primary tumor from a patient and the transplanted one from nude mice and the differences were rarely observed. Therefore, it is obvious that the patient's tumor was able to be transplanted subcutaneously in the mice during the passages when the transplanted tumors maintained their pathohisto-

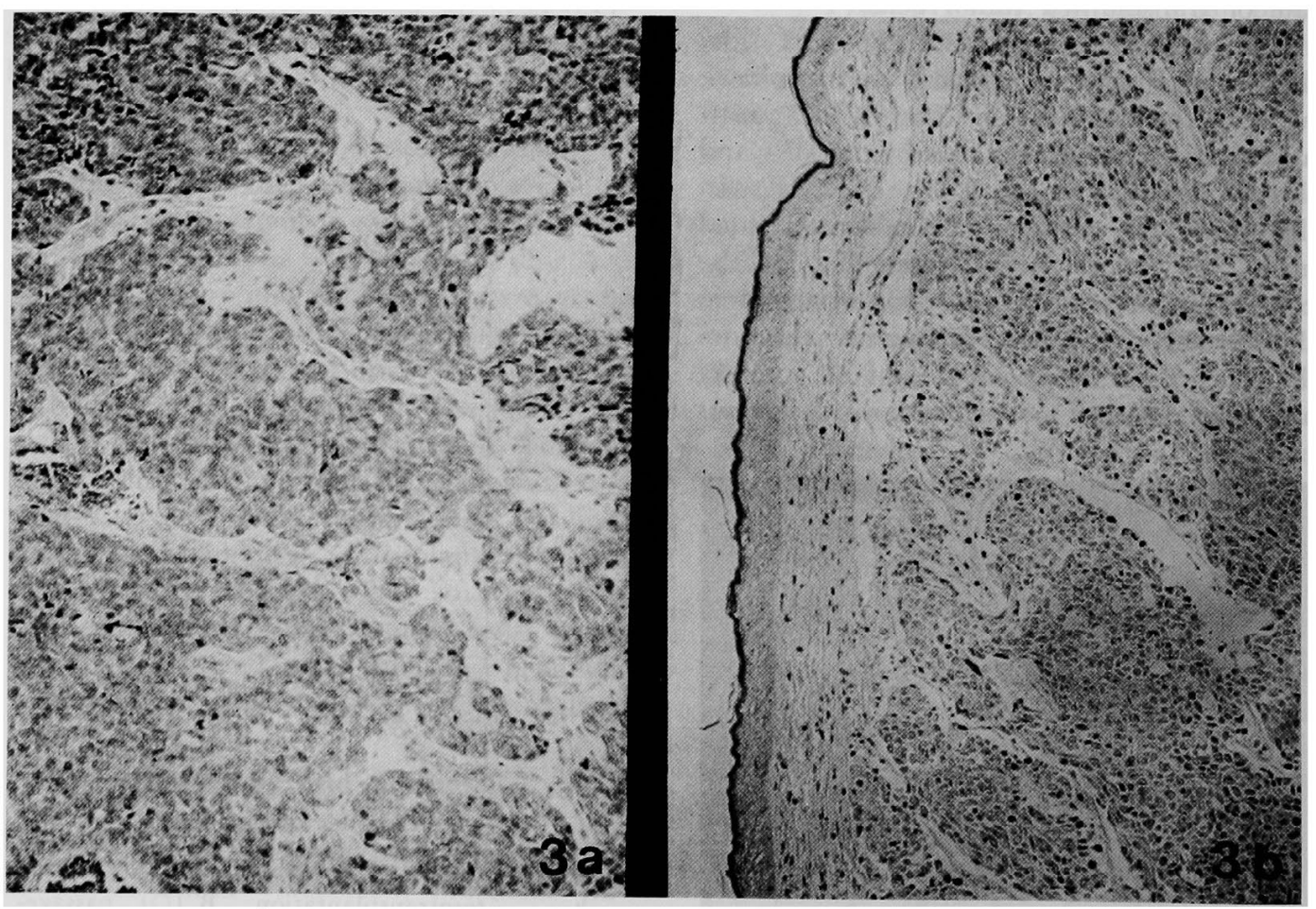

Fig. 3a A biopsied original tumor from a patient. $(40 \times)$

Fig. 3b A heterotransplanted tumor in a nude mouse. $(40 \times)$ 


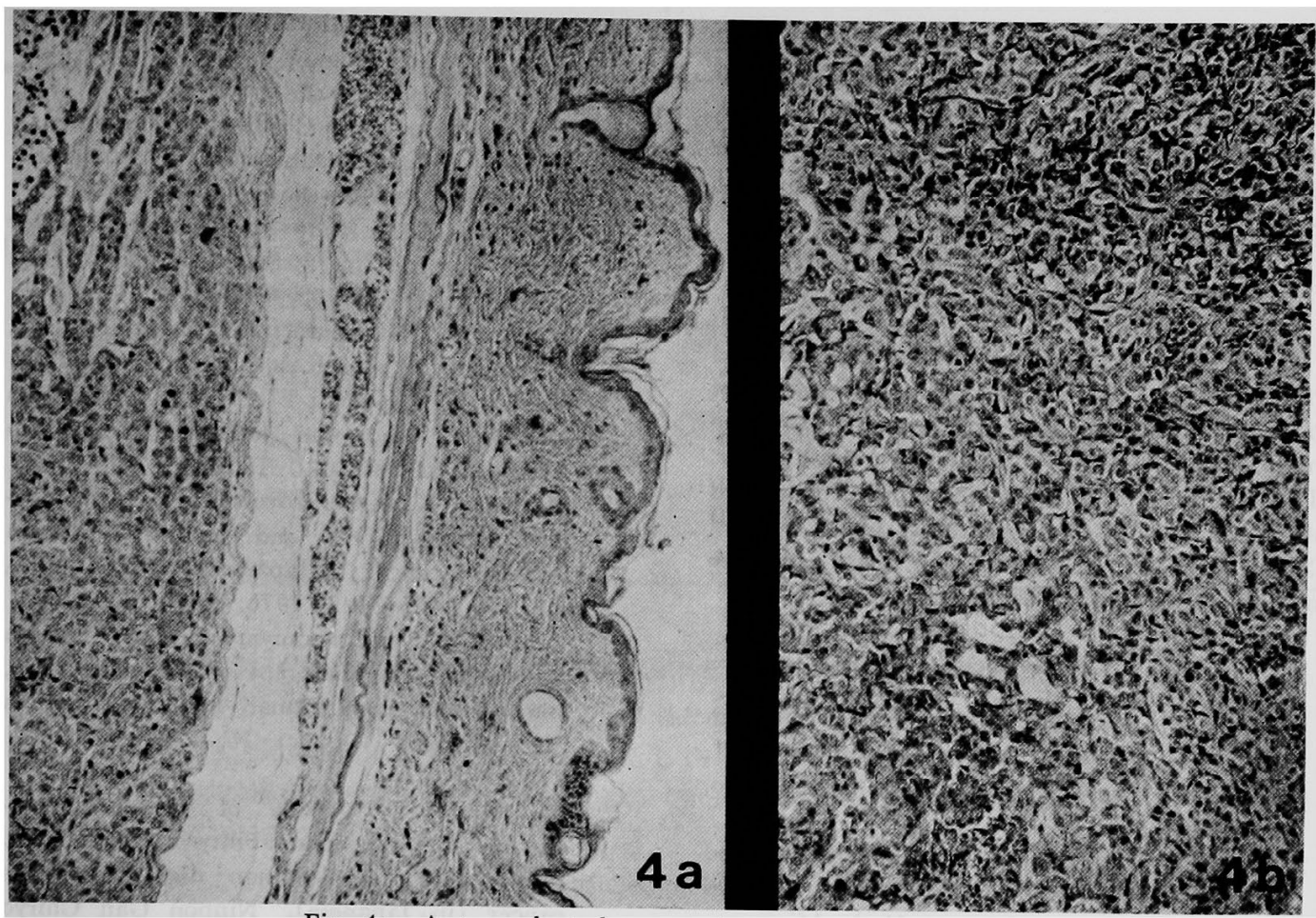

Fig. 4a A transplanted tumor for passage I. $(40 \times)$

Fig. 4b A transplanted tumor for passage II. $(40 \times)$

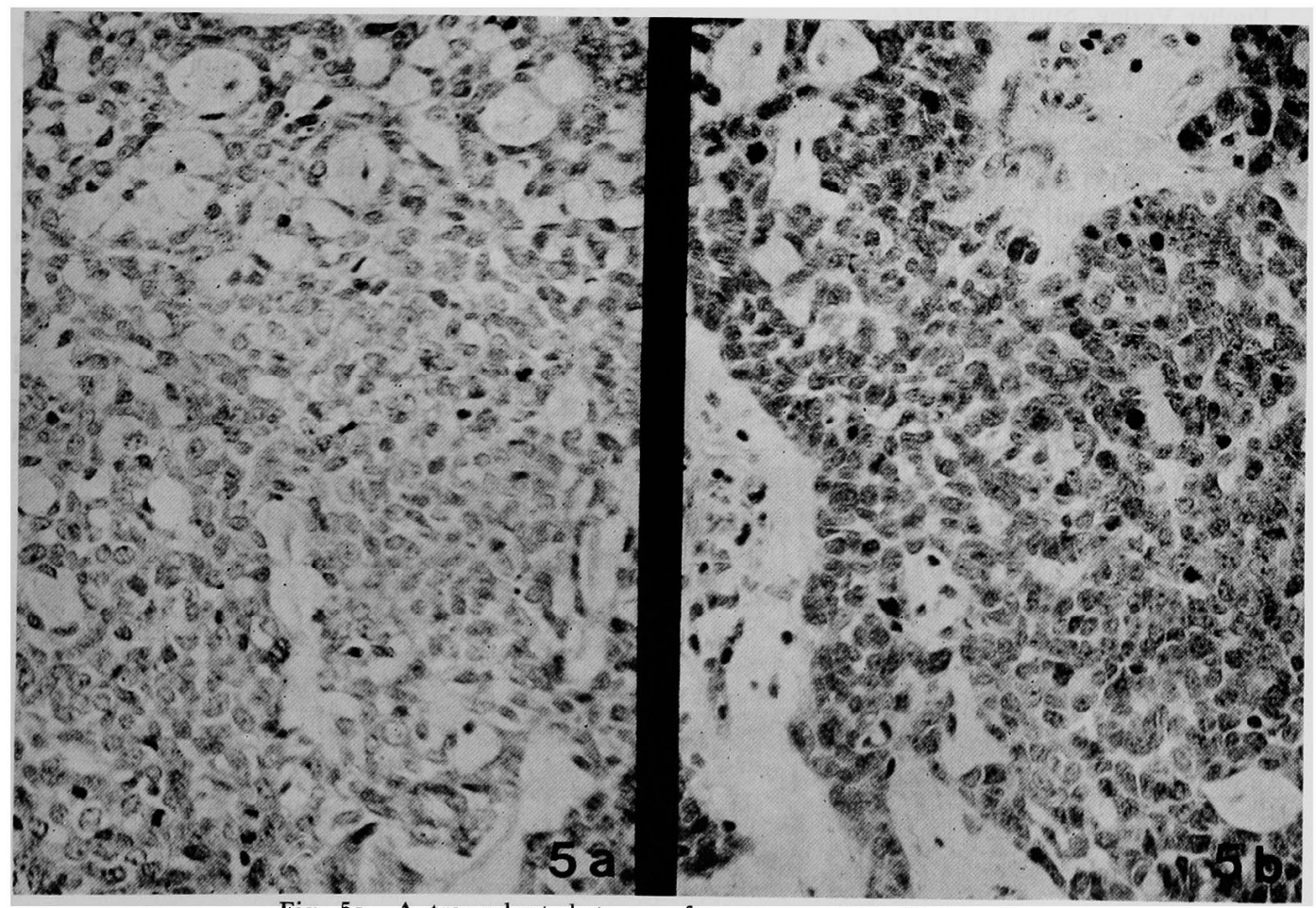

Fig. 5a A transplanted tumor for passage III. $(1000 \times)$

Fig. 5b A biopsied original tumor from patient. $(100 \times)$ 
logical characteristics. The results of the study indicate that successful transplantation of human adenoid cystic carcinoma to the nude mice, may be useful to elucidate the invasion pattern and establish a system of screening for chemotherapy.

\section{Acknowledgement}

In previous papers we have acknowledged Professor T. Seto of the 1st Department of Pathology at Teikyo University School of Medicine for his valuable advice during this study, and Dr. H. Tanaura, Mr. M. Tajmia, Mr. H. Fujita, and Mr. T. Ishiguro of the Laboratory of the Animal Center of Teikyo University, for their assistance in maintaining the experimental animals.

\section{References}

1) Shimosato, Y. and Tamaoki, N.: Human Cancer and Nude Mice. (in Japanese) 1, pp. 333-339, Ishiyakushuppan K.K., Tokyo, 1982.

2) Nomura, T., Ohsawa, N., Tamaoki, N. and Fujiwara, K. eds: Proceedings of the 2nd International Workshop on Nude Mice, pp. 587, Univ. of Tokyo press, Tokyo/Gustav Fischer Verlag, Stuttgart., 1977..

3) Shimosato, Y., Kameya, T., Nagai, K., Hirohashi, S., Koide, T., Hayashi, $H$. and Nomura, T.: Transplantation of Human Tumors in Nude Mice. J. Natl. Cancer Inst. 56(6) : 1251-1260, 1976.

4) Rygaard, J. and Povlsen, C. O.: Heterotransplantation of a human malignant tumor to "nude" mice. Acta Pathol. Microbiol. Scand. 77: 758-760, 1969.

5) Statistics and information department, minister's secretariat, Ministry of Health and Welfare eds.: Vital Statistics vol. 1 (in Japanese) pp. 184-199, Tokyo, 1982.

6) Lindenberger, J., Ganzer, U. und Fortmeyer, H. P.: Die Heterotransplantation bösartiger
Kopf und Halsgeschwulste auf thymusaplastische mackte Mause. Arch. Oto-RhinoLaryng. 220: 117-128.

7) The Japanese Tissue Culture Association eds. : Tissue Culture Techniques (in Japanese). pp. 13-14, Asakura-shoten, Tokyo, 1982.

8) Shimosato, Y.: Nude Mice, Application for cancer research (in Japanese). Tanpakushitsu Koso 23(6) : 719-732, 1978.

9) Suda, M., Kitamura, M., Nishihira, T., Watanabe, T. and Kasai, M.: Heterotransplantation of Human Esophageal Carcinomas into Nude Mice (in Japanese). Gan No Rinsho 27(2) : 18-110, 1981.

10) Tamaoki, K.: Controversal points of thymus liquid factor and cell-differentiation with nude mice (in Japanese). Nippon Rinsho 34: 3415-3422, 1976.

11) Ohsawa, N. and Kamiyama, Y.: Research for cancer chemotherapy with nude mice, transplanted from human malignant tumors (in Japanese). Igaku No Ayumi 96(5): 278-287, 1976.

12) Kawamura, E.: Study of cancer chemotherapy and transplantability in nude mice, transplanted from human digestive organs cancer (in Japanese). Nippon Gan Chiryo Gakkai Shi 13: 689-699, 1978.

13) Kiaessling, R., Klein, E., Pross, H. and Wigzell, H.: "Natural" Killer cells in the mouse II. Cytotoxic cells with specificity of killer cells. Eur. J. Immunol. 5: 117-121, 1975.

14) Herberman, R. B.: Natural cell-mediated cytotoxicity in nude mice. The nude mouse in experimental and clinical research. (Fogu, J. and Giovanella, B. C. eds.) pp. 135, Academic press, 1978.

15) Ezaki, T., Nakatani, K., Sakamoto, K., Takahashi, S., Emi, Y., Shiratori, T., and Konishi, Y.: Establishment of an $\alpha$-fetoprotein-producing human gastric carcinoma in nude mice. Gann 74: 870-877, 1983. 